\title{
Prześladowania w raju Antymuzułmańskie rozruchy na Sri Lance i ich geneza
}

W pierwszych dniach marca 2018 r. świat obiegły informacje o trwających od kilku dni rozruchach i aktach przemocy wymierzonych w lankijskich muzułmanów oraz stanie wyjątkowym, wprowadzonym przez władze wyspy w kilku najbardziej niespokojnych dystryktach. Agencje donosiły o rozlewie krwi i niszczeniu dobytku, jakich buddyjscy radykałowie dopuszczali się względem swoich muzułmańskich sąsiadów w miejscowościach centralnej i południowej Sri Lanki. Informowano o spalonych sklepach i zdemolowanych meczetach, ludziach pozbawionych w jednej chwili dachu nad głową i dorobku całego życia, braku reakcji na przemoc ze strony lankijskiej policji i zablokowanym dostępie do Internetu i mediów społecznościowych. Głównie jednak wiadomości te przekazywane były w kontekście zagrożenia, jakie opisywane wydarzenia mogą stanowić dla popularnego, również wśród polskich turystów, „raju wakacyjnego” i w zasadzie bez podejmowania jakichkolwiek prób wyjaśnienia ich przyczyn czy rzeczywistej skali ${ }^{1}$. Niniejszy tekst ma na celu uzupełnienie tej luki i przedstawienie socjo-historycznych i politycznych źródeł wystąpień antymuzułmańskich na Sri Lance ${ }^{2}$.

Muzułmanie stanowią obecnie blisko dziesięcioprocentową grupę ludności Sri Lanki ${ }^{3}$, zamieszkującą przede wszystkim dystrykty położone na wschodnim i zachodnim wybrzeżu: Ampara, Batticaloa i Trincomalee w Prowincji Wschodniej, Puttalam w Prowincji Północno-Zachodniej oraz Mannar w Prowincji Północnej, a także dystrykt Kandy w Prowincji Centralnej (zob. Il. 1).

${ }^{1}$ Zob. np.: J. Kociszewski, Buddyści dokonuja pogromów muzutmanów na Sri Lance. Przemoc zagraża turystyce, 8.03.2018, https://wiadomosci.wp.pl/buddysci-dokonuja-pogromow-muzulmanow-na-sri-lance-przemoc-zagraza-turystyce-6228010432333953a, dostęp 27.01.2019; A. Bartkiewicz, Sri Lanka: Stan wyjątkowy - buddyści bija się z muzutmanami, 6.03.2018, https://www. rp.pl/Polityka/180309650-Sri-Lanka-Stan-wyjatkowy---buddysci-bija-sie-z-muzulmanami.html, dostęp 27.01.2019; J. Muller, Buddyści kontra muzutmanie. Stan wyjątkowy na Sri Lance po rozlewie krwi, 6.03.2018, https://www.o2.pl/artykul/buddysci-kontra-muzulmanie-stan-wyjatkowy-na-sri-lance-po-rozlewie-krwi-6227263761397889a, dostęp 27.01.2019.

${ }^{2} \mathrm{~W}$ całym artykule dla uproszczenia posługuję się współczesną, wprowadzoną w 1972 r., nazwą państwa Sri Lanka także w odniesieniu do czasów, gdy zarówno wyspa, jak i położone na niej państwo, nosiły nazwę Cejlon.

${ }^{3}$ Według ostatnich danych liczba ludności Sri Lanki przekroczyła $21 \mathrm{mln}$, przy tempie wzrostu wynoszącym 0,33\%. Muzułmanie stanowią trzecią, po buddystach $(70,1 \%)$ i hindusach (12,6\%), grupę religijną zamieszkującą wyspę. Por. http://www.statistics.gov.lk/Abstract2016/ CHAP2/2.13.pdf, dostęp 27.01.2019. 
Il. 1. Liczebność i rozmieszczenie ludności muzułmańskiej na Sri Lance (dane z cenzusu z 2012 r.)

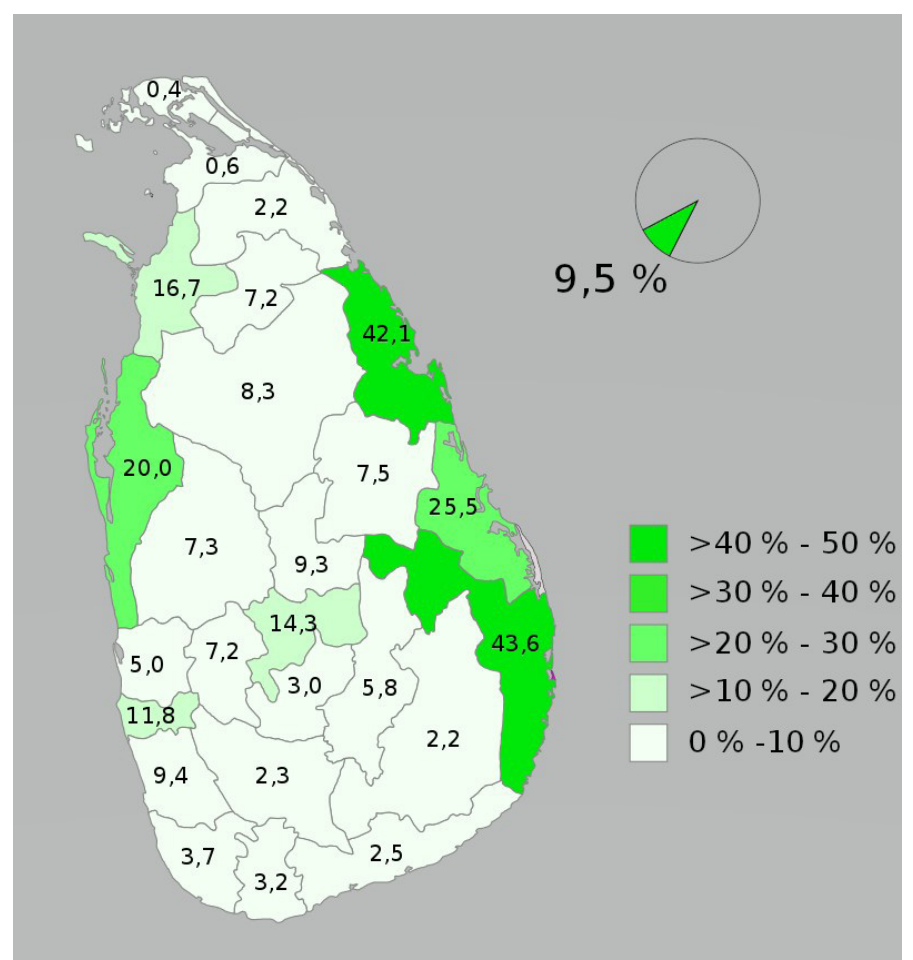

Źródło: https://en.wikipedia.org/wiki/Islam_in_Sri_Lanka\#/media/File:Islam_in_Sri_Lanka_ 2012.svg.

Na przestrzeni dziesięcioleci odsetek wyznawców islamu w ogólnej liczbie ludności Sri Lanki był względnie stały i wynosił ok. 7\%. W ostatnich latach obserwuje się jednak wzrost liczebności muzułmanów (zob. Tab. 1), co przez radykalne organizacje syngaleskie postrzegane jest jako zagrożenie dla etnicznej i religijnej supremacji Syngalezów (o czym będzie jeszcze mowa w dalszej części tekstu).

Tab. 1. Liczebność ludności muzułmańskiej na Sri Lance w XIX-XXI w.

\begin{tabular}{|l|c|c|}
\hline Cenzus & Liczebność & $\begin{array}{c}\text { Odsetek ludności } \\
\text { (w procentach) }\end{array}$ \\
\hline 1881 & 197800 & 7,17 \\
\hline 1891 & 212000 & 7,05 \\
\hline 1901 & 246100 & 6,90 \\
\hline 1911 & 283600 & 6,91 \\
\hline
\end{tabular}




\begin{tabular}{|l|c|c|}
\hline \multicolumn{1}{|c|}{ Cenzus } & Liczebność & $\begin{array}{c}\text { Odsetek ludności } \\
\text { (w procentach) }\end{array}$ \\
\hline 1921 & 302500 & 6,72 \\
\hline 1931 (szac.) & 354200 & 6,67 \\
\hline 1946 & 436600 & 6,56 \\
\hline 1953 & 541500 & 6,69 \\
\hline 1963 & 724000 & 6,84 \\
\hline 1971 & 901700 & 7,11 \\
\hline 1981 & 1121700 & 7,56 \\
\hline 2012 & 1967500 & 9,66 \\
\hline
\end{tabular}

Źródło: Oprac. własne na podstawie danych z cenzusów, http://www.statistics.gov.lk/Abstract2016/CHAP2/2.13.pdf.

Muzułmanie lankijscy nie stanowią jednorodnej grupy, dzieląc się na społeczności odrębne pod względem pochodzenia, przynależności etnicznej, języka i kultury. Przy zastosowaniu najbardziej ogólnych kryteriów podziału wyróżnia się zwykle trzy takie społeczności: Maurów, Malajów oraz muzułmanów przybyłych z Indii Zachodnich. Tym, co je łączy, pozostaje religia - choć też niejednorodna, gdyż część lankijskich muzułmanów to szyici - oraz handel, stanowiący od wieków tradycyjne zajęcie tej ludności.

Maurowie (ang. Moors), określani również tamilskim terminem Sonakar oraz syngaleskim Jonaka, to potomkowie muzułmanów docierających do Sri Lanki od VII w., którzy kontynuowali wyprawy handlowe szlakami wytyczonymi przez kupców rzymskich i arabskich jeszcze w czasach przedislamskich. Część z nich osiedlała się na wybrzeżach wyspy, zwanej przez nich wówczas Serandib ${ }^{4}$, by w ciągu kilku kolejnych dekad przejąć w zasadzie pełną kontrolę nad lankijskim handlem, zarówno zamorskim, jak i wewnętrznym. Kupcy ci zwykle brali za żony miejscowe kobiety, które przyjmowały wiarę mężów, a ich działalność handlowa i płacone przez nich podatki przyczyniały się wydatnie do rozwoju i dobrobytu lokalnych królestw, cieszyli się więc przychylnością miejscowych buddyjskich i hinduskich władców. Mieli też pełną swobodę praktykowania własnej religii i wznoszenia meczetów (najstarszy zachowany

${ }^{4}$ Ar. Sarandīb, pers. Serandīp, nazwa Sri Lanki funkcjonująca w starożytności i średniowieczu głównie w rejonie Zatoki Perskiej i w krajach arabskich, wywodząca się od sanskr. Simhaladvīpah 'lwia siedziba/wyspa'. Dokładniej zob. H. Yule, A.C. Burnell, Hobson-fobson. The Anglo-Indian Dictionary, London 1996, s. 181-182. 
i funkcjonujący do dziś meczet na Sri Lance, meczet Al Abrar w Beruwali, pochodzi z początku X w.), a słynny Szczyt Adama ${ }^{5}$, opisywany między innymi przez Ibn Battutę ${ }^{6}$, stał się jednym z najważniejszych celów muzułmańskich pielgrzymek w tej części świata.

Maurowie są największą i dominującą grupą muzułmanów na Sri Lance i to tę grupę zwykle ma się na myśli, mówiąc o lankijskich muzułmanach. Wielu z nich wywodzi swój rodowód bezpośrednio od arabskich przodków, aby zaakcentować w ten sposób własną odrębność od pozostałych społeczności muzułmańskich żyjących na wyspie. Badacze wskazują jednak na liczne podobieństwa kulturowe między lankijskimi Maurami a południowoindyjskimi wyznawcami islamu z Kerali (Mapillowie) i Tamilnadu (Marakkarowie), które mogą świadczyć o wspólnym pochodzeniu tych grup ${ }^{7}$. Mimo podobieństw Maurowie wyraźnie podkreślają jednak swoją odrębność etniczną, nie utożsamiając się ani z Tamilami, ani z Syngalezami (inaczej niż czynią to chrześcijanie czy muzułmanie w Indiach Południowych). Obecnie większość badaczy zgadza się, że mamy w tym przypadku do czynienia z ewolucją tożsamości od grupy religijnej do grupy etnicznej, z jedynym właściwie wyznacznikiem przynależności - islamem ${ }^{8}$.

Drugą pod względem liczebności grupę wyznawców islamu na Sri Lance (ok. 4\% wszystkich muzułmanów zamieszkujących wyspę ${ }^{9}$ ) stanowią Malajowie, którzy przybywali tu głównie z terenów Jawy i innych wysp Indonezji $\mathrm{w}$ kilku falach migracyjnych. Pierwsza miała miejsce jeszcze $\mathrm{w}$ początkach XIII stulecia, kiedy ówczesny władca Półwyspu Malajskiego, król Ćandrabhanu, najechał i pokonał lankijskie królestwo Pollonaruwy i założył w północnej części wyspy (dzisiejsza Dżafna) krótkotrwałe malajskie państwo. Jego szybki

\footnotetext{
${ }^{5}$ Adam's Peak - angielska nazwa góry Sri Padakanda (syng. Śrīpādakanda), usytuowanej w południowo-zachodniej części Sri Lanki, o wysokości 2243 m, na której stożkowatym szczycie znajduje się podłużne kamienne wyżłobienie o długości nieco ponad 1,5 $\mathrm{m}$ i szerokości ok. $60 \mathrm{~cm}$, przypominające odcisk ludzkiej stopy. Ważne miejsce pielgrzymek buddystów, muzułmanów i hindusów, którzy uważają, że jest to - odpowiednio - odcisk stopy Buddy, Adama lub boga Śiwy.

${ }^{6}$ Ibn Battuta, Osobliwości miast i dziwy podróży 1325-1354. Wybór, red., wybór i przedm. A. Zajączkowski, Warszawa 1962, s. 259-260 i passim.

${ }^{7}$ Najważniejsze z nich to przynależność do sunnickiej szkoły szafi'ickiej, posługiwanie się (podobnie jak Marakkarowie) językiem tamilskim i pismem arwi (bazującym na alfabecie arabskim systemem zapisu języka tamilskiego) oraz specyficzny, oparty na tradycji matrylokalnej i matrylinearnej system społeczny (tamil. kudi 'ród, pochodzenie'). Więcej zob. D. McGilvray, Arabs, Moors and Muslims: Sri Lankan Muslim Ethnicity in Regional Perspective, [w:] Muslim Communities of South Asia. Culture, Society and Power, ed. T.N. Madan, Delhi 2001, s. 507-510. O systemie kudi wśród tamilskojęzycznych muzułmanów Sri Lanki zob. także idem, Crucible of Conflicts. Tamil and Muslim Society on the East Coast of Sri Lanka, Durham-London 2008, s. 266 i n.

${ }^{8}$ Problem samoidentyfikacji muzułmanów lankijskich omawia dokładniej M.A. Nuhman, Sri Lankan Muslims. Ethnic Identity within Cultural Diversity, Colombo 2007 (zwł. rozdział 1: Language, Religion and Ethnicity. The Case of Sri Lankan Muslims).

${ }^{9}$ Ibidem, s. 20.
} 
kres nastąpił wskutek inwazji południowoindyjskich Pandiów, zaś pozostali na Sri Lance malajscy przybysze wkrótce ulegli całkowitej asymilacji z miejscową ludnością ${ }^{10}$. Współczesna społeczność lankijskich Malajów wywodzi się głównie od jawajskich zesłańców politycznych (członków rodów książęcych, przedstawicieli arystokracji i dowódców wojskowych), żołnierzy oraz robotników kontraktowych, którzy przybyli na wyspę z okupowanej przez Holandię Jawy w okresie holenderskich rządów kolonialnych na Sri Lance (1658-1796), a także żołnierzy sprowadzonych z Półwyspu Malajskiego na potrzeby kolonialnej armii brytyjskiej w wieku XIX. Lankijscy Malajowie zamieszkują w przeważającym stopniu region Kolombo i zachowują odrębność kulturową, opartą przede wszystkim na kultywowaniu własnego języka (kreolizowana forma malajskiego znana jako „lankijski malajski” $\left.{ }^{11}\right)$, choć obecnie większość Malajów posługuje się także syngaleskim i w mniejszym stopniu tamilskim oraz angielskim. Członków tej społeczności cechują także odmienne cechy fizyczne. W czasach dominacji brytyjskiej znaczna część Malajów znajdowała zatrudnienie $\mathrm{w}$ administracji, policji, straży pożarnej i wojsku, co również sprzyjało zachowaniu społecznej i kulturowej odrębności od innych grup muzułmańskich, w szczególności od dominujących liczebnie Maurów. W niepodległej Sri Lance Malajowie utracili jednak wysoką pozycję i niezależną reprezentację polityczną i obecnie społeczność ta boryka się z bezrobociem, dyskryminacją zawodową oraz obawami o dalsze zachowanie własnej odrębnej tożsamości ${ }^{12}$.

Pozostałe mniejszości muzułmańskie żyjące na Sri Lance to potomkowie osób, które w okresie panowania brytyjskiego przybyły z Indii Zachodnich, najczęściej w celach biznesowych. Należą do nich członkowie takich społeczności, jak Bohra i Chodźa, wywodzący się z Gudźaratu czy Memon, pochodzący z Sindhu. Ich liczebność jest stosunkowo niewielka, w sumie nie przekracza dziesięciu tysięcy osób ${ }^{13}$, zamieszkujących przede wszystkim dystrykty Kolombo i Kandy. Tradycyjnym zajęciem tych grup pozostaje import i eksport towarów (tekstylia, żywność i in.), jednak każda z nich utrzymuje własną odrębność kulturową i etniczną, między innymi poprzez zachowanie reguły ścisłej endogamii, a także religijną - Bohra i Chodźa to ismailickie społeczności szyickie, podczas gdy Memon należą do sunnickiej szkoły hanafickiej.

Stopniowa integracja muzułmanów z syngaleskim społeczeństwem przebiegała w wyjątkowo pokojowej i niezakłóconej atmosferze, całkiem odmiennej

${ }^{10}$ B.A. Hussainmiya, Malays in Sri Lanka Series, part 1: Malays in Sri Lanka, „Borneo Bulletin", 4.08.2001.

${ }^{11}$ Więcej zob. S. de Silva Jayasuriya, Sri Lankan Malay. A Unique Creole, [w:] Studies in Malay Dialects, ed. U. Tadmor, part 3, Jakarta 2002, s. 43-59.

${ }^{12}$ B.A. Hussainmiya, Malays in Sri Lanka Series, part 6: Life after the Regiment, „Borneo Bulletin”, 15.09.2001; M.A. Nuhman, op. cit., s. 20-25.

${ }^{13}$ Liczebność lankijskich społeczności Bohra i Chodźa szacuje się łącznie na ok. 3000 osób, Memon - na ok. 6000 osób, por. M.A. Nuhman, op. cit., s. 17-20. 
od okoliczności, jakie towarzyszyły pojawieniu się islamu w innych rejonach świata - chociażby w nieodległych północnych Indiach, dokąd muzułmanie przybywali z zamiarem zdobycia i podporządkowania sobie nowych terenów. Na Sri Lance islam pozostawał prywatną sprawą przybyszów, docierających tam w pokojowych, handlowych celach, którzy z upływem czasu zyskiwali szacunek i zaufanie miejscowej ludności. Zapewne niebagatelną rolę odegrały $\mathrm{w}$ tym procesie również buddyjskie idee tolerancji i przyjaznego nastawienia do innych, a także brak czynnika ekonomicznego, który mógłby stać się zarzewiem konfliktu. Syngalezi bowiem sami niechętnie zajmowali się handlem i z zadowoleniem odstępowali ten aspekt życia gospodarczego wyspy nowo przybyłym $^{14}$. Ułatwiało to znacząco zgodne współistnienie w obrębie jednego społeczeństwa, sprzyjało także bogaceniu się kupców muzułmańskich (poza okresem prześladowań w XVI i pierwszej połowie XVII w. ze strony portugalskich władz wyspy, pragnących przejąć i całkowicie zmonopolizować lankijski handel ${ }^{15}$ ). Wielu spośród nich dorobiło się, szczególnie w XIX w., sporych majątków i - nierzadko przy wsparciu brytyjskich władz kolonialnych - odgrywało znaczącą rolę w życiu gospodarczym i politycznym Sri Lanki.

Trwające przez wieki społeczna harmonia i pokojowa koegzystencja zostały po raz pierwszy wystawione na poważną próbę wraz z rozwojem syngaleskiego ruchu nacjonalistycznego w początkach XX w. Jego przywódcy, na czele z charyzmatycznym Anagariką Dharmapalą (1864-1934), nawoływali do podjęcia konkretnych działań „w celu usunięcia tej przeklętej grupy [tj. Maurów - A. K.-F.] z kraju”, zaś syngaleska prasa codzienna piętnowała muzułmanów jako „odwiecznych nieprzyjaciół”"

W maju 1915 r. w Kandy doszło do pierwszych starć między buddyjskimi Syngalezami i muzułmanami, protestującymi przeciwko organizowaniu buddyjskiej procesji religijnej, której towarzyszyła głośna muzyka, a której trasa przebiegała obok meczetu ${ }^{17}$.

${ }^{14}$ Więcej na ten temat zob. L. Dewaraja, The Muslims of Sri Lanka. One Thousand Years of Ethnic Harmony 900 to 1915, Colombo 1994.

${ }^{15}$ Zob. Muslims in Portuguese Sri Lanka (1505-1658) - Wars. Expulsions \& Survival, Sri Lanka Museum of Muslims. History, Culture \& Religion, http://www.srilankamuslims.org/muslims -in-portuguese-sri-lanka/, dostęp 29.01.2019.

${ }^{16}$ Zob. S.J. Tambiah, Buddhism Betrayed? Religion, Politics, and Violence in Sri Lanka, Chicago -London 1992, s. 7.

${ }^{17}$ Należy zaznaczyć, że z protestem wystąpili tzw. indyjscy Maurowie (ang. Indian Moors) - muzułmanie, którzy w wieku XIX przybyli na Sri Lankę z południowych Indii. Według danych cenzusu z 1911 r. było ich ok. 33,5 tysiąca. Posiadali obywatelstwo Indii Brytyjskich, jednak chętnie osiedlali się na wyspie, prowadząc głównie działalność handlową i niejednokrotnie przejmując w skali lokalnej pełną kontrolę nad importem, sprzedażą i dystrybucją ryżu oraz innych towarów. Tak zwani Maurowie cejlońscy, czyli muzułmanie zamieszkujący wyspę od wielu pokoleń, nigdy nie zgłaszali sprzeciwu wobec ceremonii religijnych odprawianych przez przedstawicieli innych wyznań. 
Prowadzony na płaszczyźnie prawnej spór przekształcił się w niedługim czasie w uliczne zamieszki, nasilone między innymi sprzecznymi rozstrzygnięciami brytyjskich władz, które raz wydawały zezwolenie na przejście kontrowersyjnej procesji, a raz zalecały jej powstrzymanie. Wymierzone w muzułmanów rozruchy rozprzestrzeniły się - przy mocno zachowawczej postawie sił brytyjskich - z Kandy na prowincje północne, zachodnie i południowe, angażując tysięczne tłumy i zmuszając władze kolonialne do wprowadzenia stanu wojennego.

Lokalna policja brytyjska, wspierana przez oddziały Pańdźabczyków służących w Armii Brytyjskiej, rozpoczęła pacyfikowanie Syngalezów, które przyniosło setki wyroków skazujących na chłostę lub więzienie - niejednokrotnie niesłusznych, bowiem nieznający języka syngaleskiego żołnierze pańdźabscy nie byli w stanie porozumieć się z miejscową ludnością - za posiadanie przedmiotów zrabowanych muzułmanom podczas zamieszek. Brytyjczycy dokonali także licznych aresztowań wśród syngaleskich elit, osłabiając w ten sposób na pewien czas syngaleski ruch nacjonalistyczny. Według oficjalnych danych rządowych w antymuzułmańskich rozruchach z 1915 r. zginęło 25 osób (według innych źródeł - 116), 189 osób zostało rannych, splądrowano 4075 domów i sklepów, a 250 spalono, spalono też 17 meczetów, zaś dalszych 86 meczetów zostało mniej lub bardziej zniszczonych ${ }^{18}$. I chociaż ostra reakcja brytyjskich władz pozwoliła przywrócić w kraju spokój (stan wojenny został zniesiony po dwóch miesiącach), wydarzenia z 1915 r. wyznaczają początek napięć etnicznych, które w niepodległej Sri Lance będą narastały zarówno pod względem liczby, jak i intensywności.

Kolejna odsłona konfliktu nastąpiła po przełomowym roku 1956, kiedy buddyjski syngaleski ruch nacjonalistyczny zdobył zdecydowaną przewagę na politycznej scenie Sri Lanki i zdołał m.in. doprowadzić do ogłoszenia języka syngaleskiego jedynym językiem urzędowym kraju ${ }^{19}$. Muzułmanie, w większości tamilskojęzyczni (zwłaszcza z prowincji północnych i północno-wschodnich), początkowo sympatyzowali z Tamilami i wspierali ich w „walce o język”, a gdy w 1976 r. powstała LTTE (Tygrysy Wyzwolenia Tamilskiego Ilamu), część młodzieży muzułmańskiej wstąpiła w szeregi organizacji. Wkrótce jednak radykalizacja poglądów nasilająca się wśród Tamilów i ich postępujący ekskluzywizm spowodowały, że muzułmanie, z obawy przed staniem się mniejszością w ewentualnym mniejszościowym państwie tamilskim, nie tylko

\footnotetext{
${ }^{18}$ C.A. Gunawardena, Encyclopedia of Sri Lanka. Revised Edition 2006, New Delhi 2006, s. 312-313.

${ }^{19}$ Syngaleski zastąpił w tej funkcji język angielski. Por. Official Language Act No. 33 of 1956 (zwana też Sinhala Only Act), http://shodhganga.inflibnet.ac.in/bitstream/10603/167063/15/15_ annexure\%202.pdf, dostęp 29.01.2019. Język tamilski nie został uznany za równorzędny język urzędowy, co stało się jedną z przyczyn narastającego konfliktu syngalesko-tamilskiego, który doprowadził w efekcie do wybuchu trwającej ponad ćwierć wieku (1983-2009) wojny domowej.
} 
wycofali poparcie dla działań podejmowanych przez LTTE $^{20}$, ale coraz wyraźniej zaczęli podkreślać własną odrębność etniczną i niezależność polityczną ${ }^{21}$, a nawet forsować $\mathrm{w}$ rozmowach $\mathrm{z}$ syngaleskimi władzami ideę autonomicznego muzułmańskiego regionu, który miałby objąć wschodnie i częściowo północne tereny wyspy ${ }^{22}$.

Wraz z eskalacją konfliktu syngalesko-tamilskiego w drugiej połowie lat 80 . sytuacja muzułmanów na obszarach kontrolowanych przez LTTE (prowincje na północy i północnym-wschodzie) stawała się coraz bardziej niepewna. Tamilscy nacjonaliści oskarżali ich o lojalizm względem syngaleskich władz kraju; te z kolei, oceniając głównie przez pryzmat języka, postrzegały ich jako Tamilów i podejrzewały o popieranie separatystów ${ }^{23}$. Rok 1990 stał się przełomem w stosunkach między społecznością muzułmańską a dominującą grupą bojowników tamilskich - w październiku tego roku LTTE przeprowadziła masakry muzułmanów na wschodzie i masowe czystki na północy wyspy, wypędzając wyznawców islamu pod groźbą śmierci z kontrolowanych przez siebie terenów Prowincji Północnej (gdzie muzułmanie mieli 48 godzin na opuszczenie swych domów i ucieczkę) i Dżafny (tu ultimatum wynosiło zaledwie 2 godziny). W rezultacie zmuszono do przesiedlenia ok. 72 tys. osób, z których większość do dziś mieszka w przypominających slumsy obozach, głównie w dystrykcie Puttalam w Prowincji Północno-Zachodniej. Oficjalne przeprosiny ze strony LTTE i uznanie akcji za „polityczną pomyłkę” w 2002 r. nie zmieniły w żaden sposób sytuacji wysiedleńców. Po zakończeniu działań wojennych w 2009 r. niespełna 20\% wypędzonych muzułmanów wróciło do domów. Pozostali wciąż traktowani są jak uchodźcy wewnętrzni (IDP) i nie posiadają pełni praw cywilnych ${ }^{24}$.

${ }^{20}$ Przejawiło się to m.in. biernym wsparciem dla strony rządowej po wydarzeniach tzw. czarnego lipca w 1983 r., kiedy to doszło do zakrojonych na wielką skalę pogromów ludności tamilskiej na Sri Lance.

${ }^{21} \mathrm{~W}$ dniu 21 września 1981 r. została założona pierwsza partia polityczna mająca reprezentować wyłącznie interesy lankijskich muzułmanów - Sri Lanka Muslim Congress.

${ }^{22}$ Zob. M.A. Yusoff, N. Hussin, A. Sarjoon, Muslim Demand for Territorial Autonomy in the Eastern Sri Lanka. An Analysis of Its Origin, Accommodation and the Present Stance, „Asian Social Science” 2014, Vol. 10, No. 15, s. 76-88.

${ }^{23}$ Więcej zob. D.B. McGilvray, M. Raheem, Muslim Perspectives on the Sri Lankan Conflict (Policy Studies 41), Washington 2007, s. 18 i n.

${ }^{24}$ Zob. A.R.M. Imtiyaz, M.C.M. Iqbal, The Displaced Northern Muslims of Sri Lanka. Special Problems and the Future, „Journal of Asian and African Studies” 2011, Vol. 46(4), s. 375-389; M.S. Asees, Internally Displaced People (IDPs) and Their Vulnerability. A Case Study of Muslim IDPs in Sri Lanka, „The World of Monotheistic Religions” 2010, Vol. 1, s. 96-109. 
Il. 2. Kierunki migracji muzułmanów wypędzonych w 1990 r. przez LTTE z terenów północnych
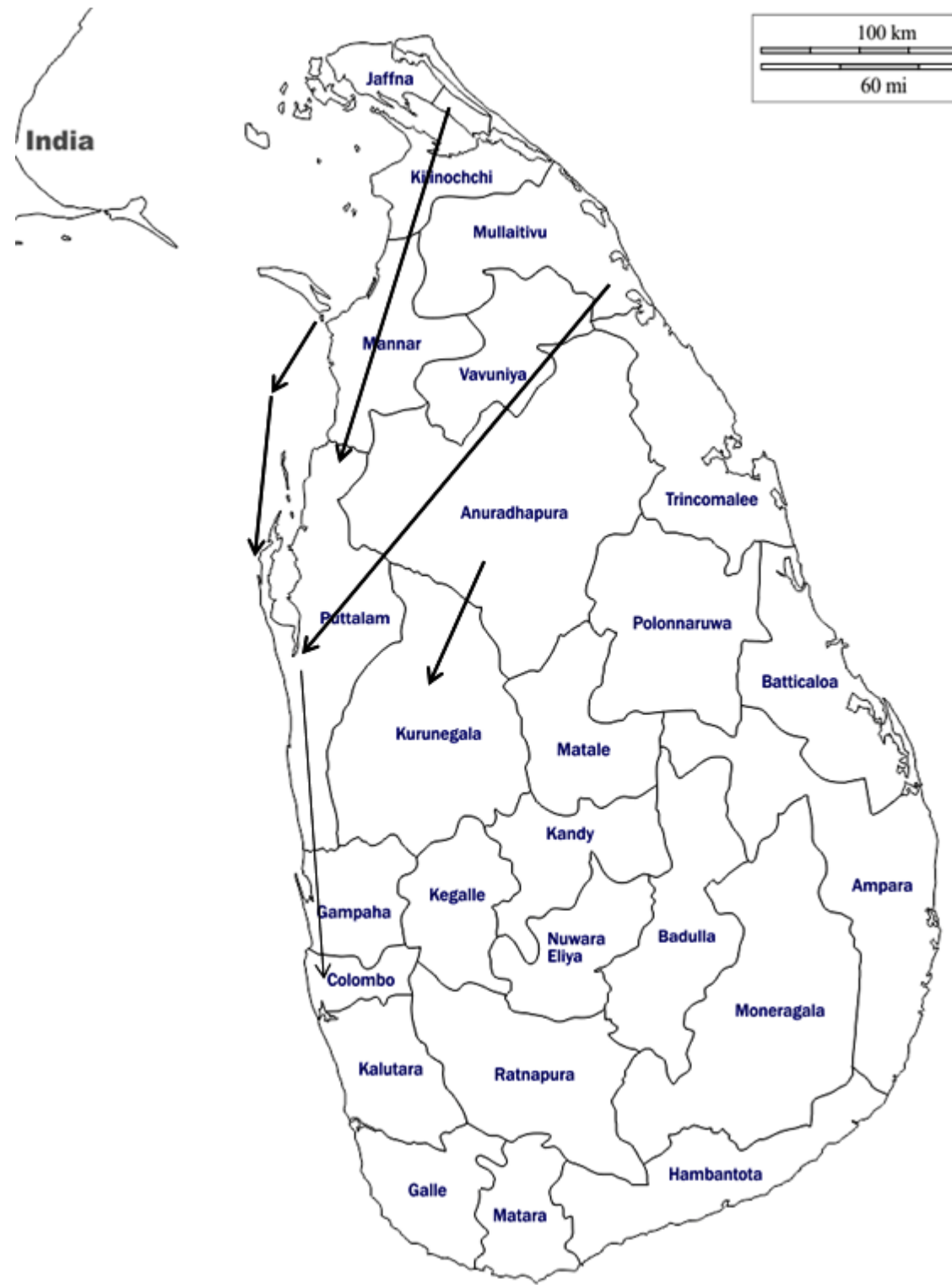

Źródło: oprac. własne na podstawie M.S. Asees, Internally Displaced People (IDPs) and Their Vulnerability. A Case Study of Muslim IDPs in Sri Lanka, „The World of Monotheistic Religions” 2010, Vol. 1, s. 102. 
Pokonanie Tamilskich Tygrysów i kres konfliktu syngalesko-tamilskiego nie oznaczały jednak zmiany sytuacji lankijskich muzułmanów na lepsze. Wręcz przeciwnie, jak stwierdzają niektórzy komentatorzy sytuacji politycznej Sri Lanki, po blisko sześciu dekadach budowania syngalesko-buddyjskiej supremacji w oparciu o wizerunek Tamila-wroga, teraz, po zlikwidowaniu LTTE, syngalescy ekstremiści potrzebowali nowego nieprzyjaciela, by móc kontynuować rozpoczęty proces w podobnym duchu. Muzułmańska mniejszość, akcentująca swą etniczną i religijną odrębność, doskonale nadawała się do tej roli ${ }^{25}$.

Działania wymierzone bezpośrednio w „muzułmański ekstremizm i chrześcijański fundamentalizm" podejmuje skrajna syngaleska buddyjska organizacja nacjonalistyczna Bodu Bala Sena (BBS, dosł. Siła Obrony Buddyjskiej), założona w 2012 r. przez ultraprawicowych mnichów buddyjskich Kiramę Wimalajothę i Galagodę Atthe Gnanasarę. BBS prezentuje się jako apolityczne stowarzyszenie społeczno-kulturalne, promujące buddyjską filozofię oraz kulturę i dziedzictwo Syngalezów, powołane do bezpośredniej interwencji w każdej sytuacji zagrożenia tych wartości ${ }^{26}$. W rzeczywistości organizacja działa jako rodzaj policji moralnej, która posługując się językiem propagandy, graniczącym z mową nienawiści, wysuwa wiele postulatów, mających przeciwdziałać „agresywnej taktyce islamskich dżihadystów działających na Sri Lance i stanowiących szczególne zagrożenie dla buddyzmu"27.

Przywódcy BBS domagają się między innymi ograniczenia dostępności środków kontroli urodzin, takich jak wazektomia, podwiązanie jajników czy środki antykoncepcyjne, wskazując na rosnącą dysproporcję między tempem przyrostu naturalnego wśród muzułmanów i wśród Syngalezów, dostrzegając w niej wielkie zagrożenie dla syngaleskiej supremacji. Nawołują także do wprowadzenia zakazu wyjazdu syngaleskich kobiet do pracy w krajach Zatoki Perskiej, zakazu budowy na Sri Lance meczetów finansowanych przez kraje Bliskiego Wschodu czy zakazu noszenia burek i abaji. W ramach walki na płaszczyźnie ekonomicznej wysuwają oskarżenia pod adresem zarządzanych przez muzułmanów sieciówek odzieżowych (np. Fashion Bug i No Limit), zarzucając im prowadzenie przymusowych konwersji na islam wobec ich syngaleskich pracowników oraz zachęcają do bojkotowania muzułmańskich sklepów na rzecz tych, które należą do Syngalezów. W zapamiętałej obronie bud-

${ }^{25}$ Nirupama Subramanian, in Sri Lanka's Anti-Muslim Violence, an Echo of Post-War Sinhala Triumphalism, „The Indian Express”, 7.03.2018, https://indianexpress.com/article/explained/srilanka-emergency-s-anti-muslim-violence-an-echo-of-post-war-sinhala-triumphalism-5088617/, dostęp 1.02.2019.

${ }^{26}$ Zob. np. opis organizacji i jej działań na poświęconym buddyzmowi portalu kwelos: Bodu Bala Sena, http://kwelos.tripod.com/bodu_bala_sena.htm, dostęp 1.02.2019. Por. też K. Tudor Silva, Gossip, Rumour, and Propaganda in Anti-Muslim Campaigns of the Bodu Bala Sena, [w:] Buddhist Extremists and Muslim Minorities. Religious Conflict in Sri Lanka, ed. J.C. Holt, Oxford 2016, s. $119-139$.

${ }^{27} \mathrm{Http}$ //kwelos.tripod.com/bodu_bala_sena.htm, dostęp 1.02.2019. 
dyjskich wartości działacze BBS posuwają się nawet do zapowiedzi zniszczenia meczetu z X wieku, stojącego na terenie buddyjskiego kompleksu świątynnego Kuragala w Ratnapurze ${ }^{28}$. Za swój wielki sukces natomiast uznaje BBS doprowadzenie do zniesienia procesu certyfikacyjnego dla żywności halal, w efekcie którego rząd lankijski wycofał pozwolenie dla All Ceylon Jamiyyathul Ulama ${ }^{29}$ na wydawanie certyfikatów.

Bodu Bala Sena odegrała też kluczową rolę w wywołaniu antymuzułmańskich rozruchów w czerwcu 2014 r., domagając się podczas organizowanych przez siebie wieców, aby wyciągnięte zostały konsekwencje wobec kilkorga muzułmanów oskarżanych o zaatakowanie buddyjskiego mnicha i jego kierowcy niedaleko miejscowości Aluthgama w Prowincji Zachodniej. W niedługim czasie, wskutek agresywnej agitacji, prowadzonej m.in. przez przywódcę BBS Galagodę Atthe Gnanasarę, zamieszki rozprzestrzeniły się poza Aluthgamę. W wyniku aktów przemocy wymierzonych w muzułmanów i ich dobytek 4 osoby poniosły śmierć, ok. 80 zostało rannych, zaś ponad $10000 \mathrm{mu}-$ siało szukać schronienia poza miejscem zamieszkania. Zniszczeniu uległy liczne należące do muzułmanów domy, sklepy, zakłady produkcyjne i meczety. Zarówno środowiska muzułmańskie, jak i międzynarodowe, zarzucały rządowi i ówczesnemu prezydentowi (a obecnemu premierowi) Mahendzie Radźapakszy oraz siłom porządkowym opieszałość reakcji i brak zaangażowania w uspokojenie sytuacji (np. nieprzestrzeganie rygoru godziny policyjnej wobec Syngalezów/mnichów). Zamiast tego rząd zalecił mediom powstrzymanie się od publikowania i komentowania informacji o rozruchach, uzasadniając to koniecznością unikania prowokowania napięć pomiędzy grupami religijnymi.

Ostatnie zakrojone na większą skalę zamieszki o charakterze komunalistycznym, wszczęte przez nacjonalistycznie zorientowanych Syngalezów i wymierzone $\mathrm{w}$ społeczność muzułmańską, miały miejsce na przełomie lutego i marca 2018 r. Ich przebieg był podobny do wydarzeń z 2014 r. - bezpośrednią przyczyną wybuchu niepokojów stała się chęć odwetu za śmierć przypadkowego syngaleskiego kierowcy ciężarówki, który wdał się w bójkę z grupą młodych muzułmanów. Zamieszki wybuchły we wschodniej części Sri Lanki (Ampara), lecz wkrótce ogarnęły też centralnie położony dystrykt Kandy i były na tyle gwałtowne, że rząd zdecydował o wprowadzeniu po raz pierwszy od 2011 r. stanu wyjątkowego i godziny policyjnej, a także blokady mediów społecznościowych, która miała uniemożliwić podżegaczom organizowanie kolejnych ataków i rozprzestrzenianie propagandy. Siły policji zostały wsparte

${ }^{28}$ Zob. C. Nathaniel, Kuragala Controversy Deepens, „The Sunday Leader”, b.d., http://www.thesundayleader.lk/2015/05/31/kuragala-controversy-deepens/, dostęp 1.02.2019; eadem, Kuragala: Buddhist Sacred Site or Sufi Shrine?, „The Sunday Leader”, b.d., www.thesundayleader.lk/2013 /06/02/kuragala-budd1hist-sacred-site-or-sufi-shrine/1, dostęp 1.02.2019.

${ }^{29}$ Wszechcejlońska Rada Ulemów - najważniejszy organ muzułmanów lankijskich, istniejący od 1924 r. i zapewniający religijne i polityczne przywództwo społeczności muzułmańskiej wyspy. 
przez oddziały wojskowe, aresztowano ponad 80 osób podejrzanych o prowokowanie do rozruchów, w tym przywódców kolejnej skrajnie nacjonalistycznej buddyjskiej organizacji Mahason Balakaya („Brygada [demona] Mahasony ${ }^{30 ”) . ~}$ W wielu miejscach Syngalezi (w tym mnisi) wspierali muzułmanów w ochronie meczetów i podczas piątkowych modlitw. Ujawniono jednak również przypadki podżegania do rozruchów przez oficerów policji oraz polityków ${ }^{31}$, co może świadczyć o tym, że wydarzenia z 2018 r. stanowiły raczej starannie zaplanowaną akcję niż spontaniczny przejaw społecznej niechęci do muzułmanów.

Il. 3. Przywódca BBS Galagoda Atthe Gnanasara podczas wiecu w Aluthgamie 15 czerwca 2014 r. $^{32}$

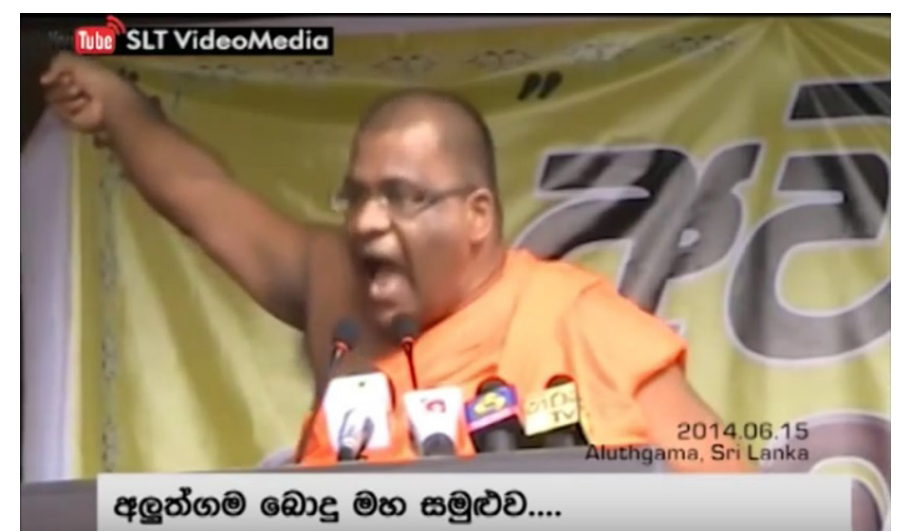

Źródło: https://www.youtube.com/watch?v=-fPMWD8f9lE, dostęp 2.02.2019.

Podejmując próbę wyjaśnienia istoty oraz przyczyn prześladowań, jakie od stulecia dotykają zamieszkującą Sri Lankę społeczność muzułmańską, należy pamiętać o kilku istotnych kwestiach, stanowiących społeczno-polityczne tło analizowanego zjawiska. Pierwszą z nich jest silne poczucie odrębności prezentowane przez lankijskich muzułmanów (Maurów), stanowiących zarówno we własnym przeświadczeniu, jak i w opinii badaczy, odrębną grupę etniczną,

\footnotetext{
${ }^{30}$ Mahasona/Mahasohona (syng. „Największy Demon”) - w syngaleskiej tradycji ludowej najbardziej przerażający spośród demonów. Nawiedza cmentarze w poszukiwaniu ludzkich szczątków do pożarcia, roznosi cholerę i dyzenterię. Wyobrażany jako blisko czterdziestometrowa postać o czerwonej skórze, mająca głowę niedźwiedzia bądź tygrysa, czworo oczu i cztery dłonie. R.F. Gombrich, G. Obeyesekere, Buddhism Transformed: Religious Change in Sri Lanka, Delhi 1990, s. 117.

${ }^{31}$ Zob. Afreen, Police and Politicians Accused of Anti-Muslim Riots in Sri Lanka, „The Siasat Daily”, 26.03.2018, https:/www.siasat.com/news/police-and-politicians-accused-joining-anti-mu slim-riots-sri-lanka-1334385/, dostęp 4.02.2019.

${ }^{32}$ Podczas wiecu padły m.in. szeroko komentowane w mediach i uznane za przejaw mowy nienawiści słowa: „Wciąż mamy syngaleską policję! Wciąż mamy syngaleskie wojsko! Jeśli jakiś marakkalaja lub inny paraja [obraźliwe określenia muzułmanina - A. K.-F.] tknie Syngaleza, to będzie koniec ich wszystkich!” Zob. Bodu Bala Sena Aluthgama Meeting 1506 2014, https://www. youtube.com/watch?v=TBIrLHBqdeM, dostęp 2.02.2019.
} 
dla której religia (islam) pozostaje ważniejszym wyznacznikiem tożsamości niż język (tamilski). W związku z tym muzułmanie nie utożsamiają się z Tamilami lankijskimi (hindusami i chrześcijanami) pomimo wspólnego z nimi języka, ani z innymi grupami muzułmańskimi (tamilskojęzyczni muzułmanie z Indii Południowych, Malajowie itd.) pomimo wyznawania tej samej religii. Tak silne poczucie własnej odrębności powoduje jednak, że są oni postrzegani przez pozostałe społeczności - szczególnie przez buddyjskich Syngalezów - jako potencjalne zagrożenie z uwagi na swą większą dzietność (co przekłada się na znaczny wzrost populacji muzułmanów w ciągu ostatnich dekad) oraz związki ekonomiczne i ideologiczne z krajami Zatoki Perskiej - w szczególności z Arabią Saudyjską. W efekcie od początku drugiej dekady XXI stulecia muzułmanie stają się coraz częściej obiektem ataków ze strony rosnącego w siłę buddyjskiego nacjonalizmu syngaleskiego. Jeśli sytuacja ta nie ulegnie zmianie, z czasem może dojść do znacznej radykalizacji środowisk muzułmańskich i ich coraz silniejszej wahhabizacji, przed którą już teraz przestrzegają niektóre kręgi muzułmańskie na Sri Lance. 